\title{
Using Probability Distribution Functions for Satellite Validation
}

\author{
David J. Lary and Leslie Lait
}

\begin{abstract}
Probability distribution functions (PDFs) can be used to assist in the validation of trace gas retrievals made by satellites. A major advantage of this approach is that large statistical samples are used that do not require correlative measurements to be co-located in space and time. Examples are shown from the launch of UARS through to the present. This approach is also useful to evaluate the consistency among Aura instruments as well as their agreement with other datasets. A key feature of this work is putting the observations of Aura in their long-term historical context via statistical comparisons with previous datasets collected over more than a decade. To validate the Aura data, we use data from a variety of platforms including solar occultation (Canadian ACE) and limb sounder satellite instruments, ozonesondes (WOUDC), lidar (NDSC), and aircraft instruments (AVE, PAVE, and MOZAIC). The width of the trace gas PDFs can be used to accurately estimate the atmospheric spatial variability (or representativeness uncertainty) of trace gases as a function of time and location. This statistical analysis is also being used as preparation for full Kalman filter chemical assimilations. The analysis is presented online at http://www.PDFCentral.info.
\end{abstract}

Index Terms-Chemical data assimilation, probability distribution functions (PDFs), representativeness uncertainty, spatial variability.

\section{INTRODUCTION}

$\mathbf{S}$ ATELLITE evaluation and validation are necessary, but sampling issues often make practical application problematic. In the traditional approach to validation we require coincidence in space and time. This is a strong constraint which dramatically reduces the statistical sample sizes we can deal with. The definition of "coincident" observations varies, but such measurements are often separated in time by days and in space by distances on the order of $1000 \mathrm{~km}$ or more. While the approach is suitable for a quick comparison to establish that the observations are at least the correct order of magnitude, establishing instrument accuracy or precision through such comparisons is difficult because of the limited number of coincidences and the contribution of real atmospheric variability. Furthermore, issues of representativeness arise because the validation exercises are typically limited geographically. It is therefore useful to augment the traditional approach to validation with the use of probability distribution functions (PDFs) of trace gases over an extended period for a given spatial domain. In this study, we choose to consider an entire month of data and to specify the spatial domain in terms of Lagrangian

Manuscript received April 29, 2005; revised July 22, 2005. This work was supported in part by the National Aeronautics and Space Administration.

The authors are with the Global Modeling and Assimilation Office, NASA Goddard Space Flight Center, GEST, University of Maryland Baltimore County, Baltimore, MD 20771 USA (e-mail: David.Lary@umbc.edu).

Digital Object Identifier 10.1109/TGRS.2005.860662 flow-tracking coordinates. The analysis starts with the launch of UARS and continues up to the present.

It is worth noting that PDFs have been used in a variety of tracer studies. These range from considering dispersing tropospheric pollutant plumes in the planetary boundary layer [1]-[6], running water channels [7] and clouds [8], pollutant emission rates [9] to tracer transport and stratospheric $\mathrm{O}_{3}$, $\mathrm{CH}_{4}, \mathrm{~N}_{2} \mathrm{O}, \mathrm{CO}, \mathrm{CO}_{2}$, and PV [10]-[25] tracer age and transit time [17], [26], [27] and estimation of representativeness uncertainty in chemical data assimilation [28]. Using PDFs for validation has been found useful by the Aura instrument teams, for example [29].

Not only does a PDF characterize the tracer distribution, its shape tells us about mixing barriers, how complete the mixing is, and chemical processes such as ozone depletion [15], [16], [23], [24]. For example, a narrow peak in the concentration PDF indicates that the air is well mixed and significant variability generating processes have not recently occurred (e.g., long range transport). A multimodal distribution indicates air of different origins (e.g., polar and midlatitude). In general, broad peaks indicate recent variability generating processes such as photochemistry or transport (horizontal or vertical). Chemical processes such as ozone depletion will lead to an asymmetric broadening of the PDF toward low ozone values. Good examples of these different cases are shown for POAM observations of ozone by Strahan et al. [23].

Measurement imprecision is one the factors that affects the widths of the PDFs, and precision of the measurements is certainly a parameter that needs validation. In many cases this is difficult because atmospheric variability swamps the effects of measurement imprecision. The PDF plots of the type described here might also help to reduce the atmospheric variability by indicating locations and conditions where it is minimized. Comparisons between measurements under these conditions could then be used to produce upper limits on measurement imprecision.

\section{A. Flow-Tracking Coordinates}

Because a major component of the variability of trace gases is due to atmospheric transport it makes sense to use a coordinate system that "follows" the large scale flow pattern to perform our analyses [80]. In this study Lagrangian flow-tracking coordinates are used.

Under adiabatic conditions air parcels move along isentropic surfaces (surfaces of constant potential temperature, $\boldsymbol{\theta}$ ) [81]-[84]. So when considering tracer fields $\boldsymbol{\theta}$ is a suitable vertical coordinate. References [85]-[88] have shown the value 
of isentropic maps of Ertel's potential vorticity (PV) for visualising large scale dynamical processes. PV plays a central role in large scale dynamics where it behaves as an approximate material tracer [87].

As a result, PV can be used as the horizontal spatial coordinate instead of latitude and longitude [89]-[96]. PV is sufficiently monotonic in latitude on an isentropic surface to act as a useful replacement coordinate for both latitude and longitude, reducing the tracer field from three dimensions to two. These ideas have already led to interesting studies correlating PV and chemical tracers such as $\mathrm{N}_{2} \mathrm{O}$ and $\mathrm{O}_{3}$ [93], [97]-[101]. A key result of these studies is that $\mathrm{PV}$ and ozone mixing ratios are correlated on isentropic surfaces in the lower stratosphere, as was first pointed out by Danielsen [83].

Since the absolute values of PV depend strongly upon height and the meteorological condition, it is useful to normalize PV and use equivalent PV latitude $\left(\phi_{e}\right)$ as the horizontal coordinate instead of PV itself. $\phi_{e}$ is calculated by considering the area enclosed within a given PV contour on a given $\theta$ surface. The $\phi_{e}$ assigned to every point on this PV contour is the latitude of a latitude circle which encloses the same area as that PV contour. Therefore, for every level in the atmosphere $\phi_{e}$ has the same range of values, $-90^{\circ}$ to $90^{\circ}$. This provides a vortex-tracking, and indeed a flow-tracking, stratospheric coordinate system. In this study we have used UKMO meteorological analyses.

\section{B. Analyses Grid}

The analyses grid used here is cast in equivalent PV latitude $\left(\phi_{\mathrm{el}}\right)$, potential temperature $(\theta)$ coordinates. With 30 latitudes between $85^{\circ} \mathrm{S}$ and $85^{\circ} \mathrm{N}$, and 21 logarithmically spaced isentropic surfaces between the earth's surface and $2500 \mathrm{~K}$. As the potential temperature at the surface changes with time we use a fixed number of isentropic levels between the current potential temperature of the surface and $315 \mathrm{~K}$. Above $315 \mathrm{~K}$, the levels remain fixed with time. The fixed isentropic levels correspond to the UARS surfaces spaced at 6 per decade in pressure (cf. the UARS reference atmosphere levels [102] of 315, 340, 375, $420,465,520,585,655,740,840,960,1100,1300,1500,1700$, $1900,2100,2300$, and $2500 \mathrm{~K}$ ).

The grid resolution was carefully chosen to ensure that there is usually a statistically significant number of observations per analysis grid cell over the entire time period from the launch of UARS in 1991 up to the present. This allows meaningful representativeness uncertainty statistics to be calculated based on the observations alone. When using equivalent PV latitude $\left(\phi_{\mathrm{el}}\right)$, potential temperature $(\theta)$ coordinates for tracer studies short periods of less than a week are usually used since equivalent PV latitude is essentially a nonlinear rescaling of PV that depends on the PV gradient and is mostly independent of the largescale average PV on the theta surface. For longer time-scales the PV-tracer correlations are not independent of the large-scale average PV. In addition there is interannual variability in the large-scale average PV. However, in this study we are using regions in equivalent PV latitude-theta space to split the atmosphere up in order to do intercomparisons between instruments where we will generally have significant sample sizes, i.e., greater than around 100 data points. We could equally well have used latitude and pressure or altitude to do this, but have found the comparison to be cleaner when we use an equivalent PV latitude - theta space [96].

\section{Constituent Datasets Used}

In this study we used observations from 33 different ozone instruments and aircraft campaigns, many of which were not available for the entire period. A full listing is given in Table I together with references.

\section{HistoricAl CONTEXT}

The number of observational datasets available is very dependent on the constituent. Ozone has the longest time record and widest array of observation platforms. It is of interest to see how the observations made by Aura fit into this decade and a half of observations made since the launch of UARS by satellite, aircraft, lidars and sondes. To do this we have constructed a complete set of PDFs of all the instruments listed above that have measured ozone at any time from the launch of the NASA UARS in October 1991 up until the present. ${ }^{1}$

Fig. 1(a) shows an example of histograms of ozone observations using data during the January of all years from the launch of UARS in September 1991 until the present in the Lagrangian region $455 K<\theta<585 K, 43^{\circ}<\phi_{\mathrm{el}}<55^{\circ}$. For this Lagrangian region observations from 13 different platforms were available including EOS Aura MLS in green, NASA aircraft campaigns in red, and a few observations from ACE in black. To put the observation histograms in context it is valuable to know exactly where the observations were located within the Lagrangian region and the associated temperatures, this can sometimes help explain any differences that may exist. Fig. 1(b)-(e) show histograms of the associated equivalent PV latitudes $\left(\phi_{\mathrm{el}}\right)$, temperatures, pressures (in megabits) and altitudes (in kilometers).

This example was chosen as there is reasonable agreement between all the sensors within the envelope observed by the aircraft campaigns (including the Aura Validation Experiment, AVE). It is clear that there is natural variability in this Lagrangian region over the month of January. Experience has shown that a helpful measure is how well the median values line up. It is interesting to note that there is good agreement (with the exception of CLAES which we shall examine further) in the median ozone volume mixing ratio (VMR) between instruments that made observations in 2004, such as MLS Aura and AVE aircraft, and others such as ILAS and MLS UARS which were from earlier years. Another use of this view of the data is that it allows us to use the data to examine the variability we expect in a constituent as a function of time and location.

It should also be noted that distributions with only a few measurements are not statistically converged (i.e., if more observations were available the shape of the histograms would change), these were only included for the sake of completeness. This is particularly so in the case of 2004 and 2005 when we would like to compare ACE and Aura, but the data volume from ACE is much smaller than that from Aura.

\footnotetext{
${ }^{1}$ These PDFs are available online at PDFCentral (gest.umbc.edu/PDFCentral/) and put the Aura data into a historical context.
} 
TABLE I

CONSTITUENT DATASETS USED IN THIS STUdY

\begin{tabular}{|c|c|c|c|c|}
\hline Instrument & Version & References & Years & Website \\
\hline \multicolumn{5}{|l|}{ Aircraft } \\
\hline $\begin{array}{l}\text { Airborne Antarctic Ozone } \\
\text { Experiment (AAOE) }\end{array}$ & & & 1987 & http://cloudl.arc.nasa.gov/aaoe/ \\
\hline $\begin{array}{l}\text { Airborne Arctic Stratospheric } \\
\text { Experiment (AASE) }\end{array}$ & & & $1988-9$ & http://cloud1.arc.nasa.gov/aase/ \\
\hline $\begin{array}{l}\text { Airborne Arctic Stratospheric } \\
\text { Experiment II (AASE 2) }\end{array}$ & & & $1991-2$ & http://cloud1.arc.nasa.gov/aase2/ \\
\hline $\begin{array}{l}\text { Stratospheric Photochemistry Aerosols } \\
\text { \& Dynamics Experiment (SPADE) }\end{array}$ & & & 1992 & http://cloud1.arc.nasa.gov/spade/ \\
\hline $\begin{array}{l}\text { Airborne Southern Hemisphere Ozone } \\
\text { Experiment (ASHOE) }\end{array}$ & & & 1994 & http://cloud1.arc.nasa.gov/ashoe_maesa/ \\
\hline Tropical Ozone Transport Experiment (TOTE) & & & $1995-6$ & \\
\hline $\begin{array}{l}\text { Stratospheric Tracers of Atmospheric } \\
\text { Transport (STRAT) }\end{array}$ & & & $1995-6$ & http://cloudl.arc.nasa.gov/strat/ \\
\hline $\begin{array}{l}\text { Subsonic Aircraft: Contrail and Clouds } \\
\text { Effects Special Study (SUCCESS) }\end{array}$ & & & 1996 & http://cloudl.arc.nasa.gov/success/ \\
\hline $\begin{array}{l}\text { Photochemistry and Ozone Loss in the } \\
\text { Arctic Region In Summer (POLARIS) }\end{array}$ & & & 1997 & http://cloud1.arc.nasa.gov/polaris/ \\
\hline Wb57 Aerosol Mission (WAM) & & & 1998 & mtp.jpl.nasa.gov/missions/wam/ \\
\hline $\begin{array}{l}\text { The SAGE III Ozone Loss \& Validation } \\
\text { Experiment (SOLVE) }\end{array}$ & & & 1999-2000 & http://cloudl.arc.nasa.gov/solve/ \\
\hline $\begin{array}{l}\text { The Cirrus Regional Study of Tropical Anvils } \\
\text { \& Cirrus Layers - Florida Area Cirrus } \\
\text { Experiment (CRYSTAL-FACE) }\end{array}$ & & & July 2002 & http://cloudl.arc.nasa.gov/crystalface/ \\
\hline $\begin{array}{l}\text { The SAGE III Ozone Loss \& Validation } \\
\text { Experiment (SOLVE II) }\end{array}$ & & & January 2003 & http://www.espo.nasa.gov/solveII \\
\hline The Pre-Aura Validation Experiment (PREAVE) & & & January 2004 & \\
\hline The Aura Validation Experiment (AVE), San Jose & & & Winter 2004 & http://cloud1.arc.nasa.gov/ave/ \\
\hline The Aura Validation Experiment (AVE), Houston & & & Fall 2004 & http://cloudl.arc.nasa.gov/ave-houston/ \\
\hline $\begin{array}{l}\text { Measurement of Ozone \& Water vapour by } \\
\text { Airbus In-service Aircraft (MOZAIC) }\end{array}$ & & {$[30]$} & 1994-present & http://www.aero.obs-mip.fr/mozaic/ \\
\hline \multicolumn{5}{|l|}{ Satellite and Shuttle Instruments } \\
\hline Atmospheric Chemistry Experiment (ACE) & $1 \& 2.1$ & {$[31]-[36]$} & 2004-present & $\begin{array}{l}\text { http://www.ace. uwaterloo.ca/index.php } \\
\text { https://databace.uwaterloo.ca/level2/ }\end{array}$ \\
\hline $\begin{array}{l}\text { The Atmospheric Trace Molecule } \\
\text { Experiment (ATMOS) }\end{array}$ & 3 & [37] & $1992-4$ & http:/remus.jpl.nasa.gov/atmos/atmos.html \\
\hline $\begin{array}{l}\text { Microwave Limb Sounder (MLS) } \\
\text { on UARS, } 183 \mathrm{GHz} \& 205 \mathrm{GHz} \text { channels }\end{array}$ & 5 & [38]-[43] & 1991-1999 & http://mls.jpl.nasa.gov/ \\
\hline $\begin{array}{l}\text { Microwave Limb Sounder (MLS) } \\
\text { on NASA EOS Aura [44], [45] }\end{array}$ & 01 & [42] & 2004-present & http://mls.jpl.nasa.gov/ \\
\hline $\begin{array}{l}\text { Cryogenic Limb Array Etalon } \\
\text { Spectrometer (CLAES) on NASA UARS }\end{array}$ & 9 & {$[46]-[48]$} & 1991-1993 & http://www.spasci.com/CLAES \\
\hline $\begin{array}{l}\text { CRyogenic Infrared Spectrometers } \\
\text { \& Telescopes for the Atmosphere (CRISTA) }\end{array}$ & & {$[49]-[51]$} & 1994,1997 & http://www.crista.uni-wuppertal.de/ \\
\hline $\begin{array}{l}\text { Halogen Occultation Experiment (HALOE) } \\
\text { on NASA UARS }\end{array}$ & 19 & {$[52]-[54]$} & 1991-present & http://haloedata.larc.nasa.gov/download/ \\
\hline $\begin{array}{l}\text { Improved Limb Atmospheric Spectrometer } \\
\text { (ILAS) on ADEOS }\end{array}$ & & {$[55]-[60]$} & $1996-7$ & http://www-ilas.nies.go.jp/ \\
\hline $\begin{array}{l}\text { Improved Stratospheric and Mesospheric } \\
\text { Sounder (ISAMS) on NASA UARS }\end{array}$ & 10 & {$[61]-[65]$} & 1991-2 & \\
\hline $\begin{array}{l}\text { Polar Ozone \& Aerosol Measurement } \\
\text { Experiment (POAM) II }\end{array}$ & 6 & {$[66]-[70]$} & $1992-6$ & http: //wvms.nrl.navy.mil/POAM/ \\
\hline $\begin{array}{l}\text { Polar Ozone \& Aerosol Measurement } \\
\text { Experiment (POAM) III }\end{array}$ & 4 & {$[66]-[70]$} & 1998-present & http://wvms.nrl.navy.mil/POAM/ \\
\hline $\begin{array}{l}\text { Stratospheric Aerosol and Gas } \\
\text { Experiment II (SAGE II) }\end{array}$ & 6.2 & {$[71],[72]$} & 1991-present & http://www-sage2.larc.nasa.gov/ \\
\hline $\begin{array}{l}\text { NOAA Solar Backscatter UltraViolet } \\
\text { Instrument (SBUV/2) }\end{array}$ & 8 & {$[73]-[76]$} & 1991-present & \\
\hline Ground-based Instruments and Sondes & & & & \\
\hline $\begin{array}{l}\text { Lidar and microwave observations from the } \\
\text { Network for the Detection for } \\
\text { Stratospheric Change (NDSC) }\end{array}$ & & {$[77]-[79]$} & 1991-present & ftp://ndsc.ncep.noaa.gov/ \\
\hline $\begin{array}{l}\text { Ozone sondes from the World Ozone } \\
\text { \& Ultraviolet Radiation Data Centre (WOUDC) }\end{array}$ & & & 1991-present & http://www.woudc.org/index_e.html \\
\hline
\end{tabular}


All years $01\left(455 \mathrm{~K}<\theta<585 \mathrm{~K}, 43^{\circ}<\phi_{\text {el }}<55^{\circ}\right)$

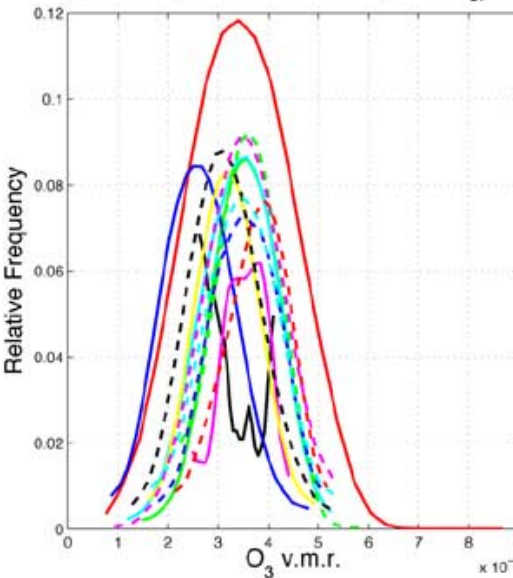

(a)

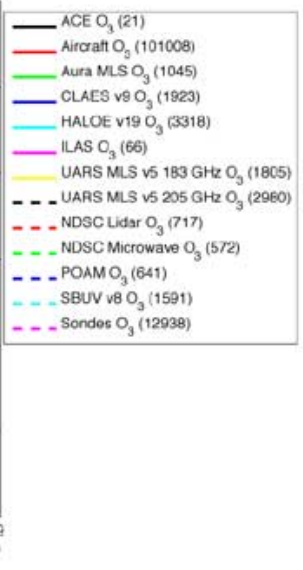

All years $01\left(455 \mathrm{~K}<\theta<585 \mathrm{~K}, 43^{\circ}<\phi_{\mathrm{el}}<55^{\circ}\right)$
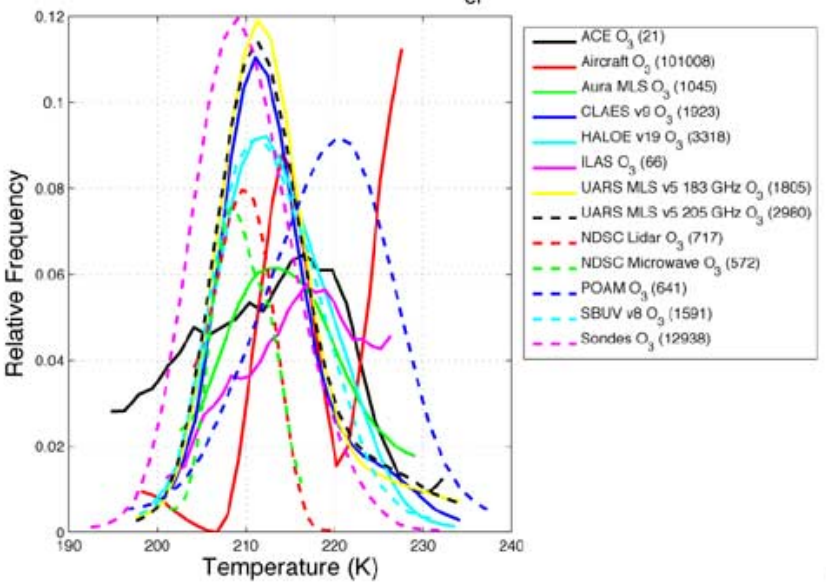

All years $01\left(455 \mathrm{~K}<\theta<585 \mathrm{~K}, 43^{\circ}<\phi_{e l}<55^{\circ}\right)$

(b)

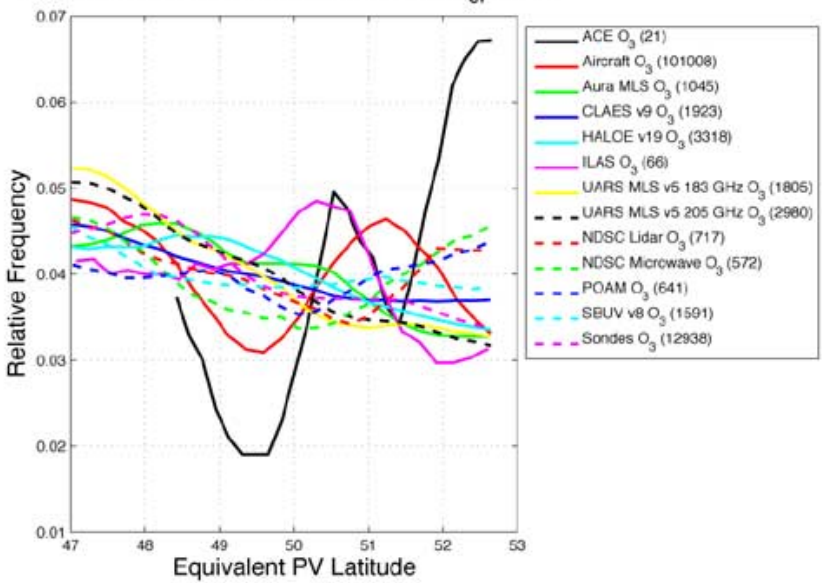

All years $01\left(455 \mathrm{~K}<\theta<585 \mathrm{~K}, 43^{\circ}<\phi_{\mathrm{el}}<55^{\circ}\right)$



(d)

(c)

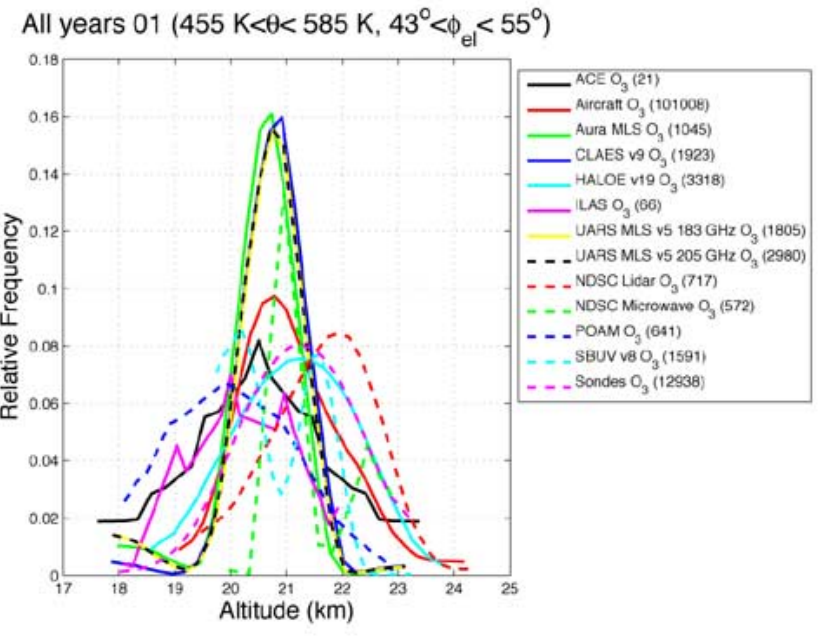

(e)

Fig. 1. (a) Example of histograms of ozone observations using data during the January of all years from the launch of UARS in September 1991 until the present in the Lagrangian region $455 K<\theta<585 K, 43^{\circ}<\phi_{\mathrm{el}}<55^{\circ}$. For this Lagrangian region observations from 13 different platforms were available including EOS Aura MLS in green, NASA aircraft campaigns in red, and a few observations from ACE in black. To put the observation histograms in context it is valuable to know exactly where the observations were located within the Lagrangian region and the associated temperatures, this can sometimes help explain any differences that may exist. (b)-(e) Histograms of the associated equivalent PV latitudes $\left(\phi_{\mathrm{el}}\right)$, temperatures, pressures (in millibits) and altitudes (in kilometers).

\section{BIAS DETECTION}

In some cases, using PDFs affords clear bias detection. For example, Fig. 2 shows ozone PDFs for observations made by UARS CLAES (red line) and seven other instruments including ISAMS (red line) during the January of all years from the launch of UARS in September 1991 until the present in the Lagrangian region $1900 K<\theta<2300 K,-90^{\circ}<\phi_{\mathrm{el}}<-79^{\circ}$. For this Lagrangian region observations from seven different platforms were available including EOS Aura MLS in black. There is a clear low bias of CLAES between contemporary measurements such as ISAMS (green line) and UARS MLS (navy and cyan 


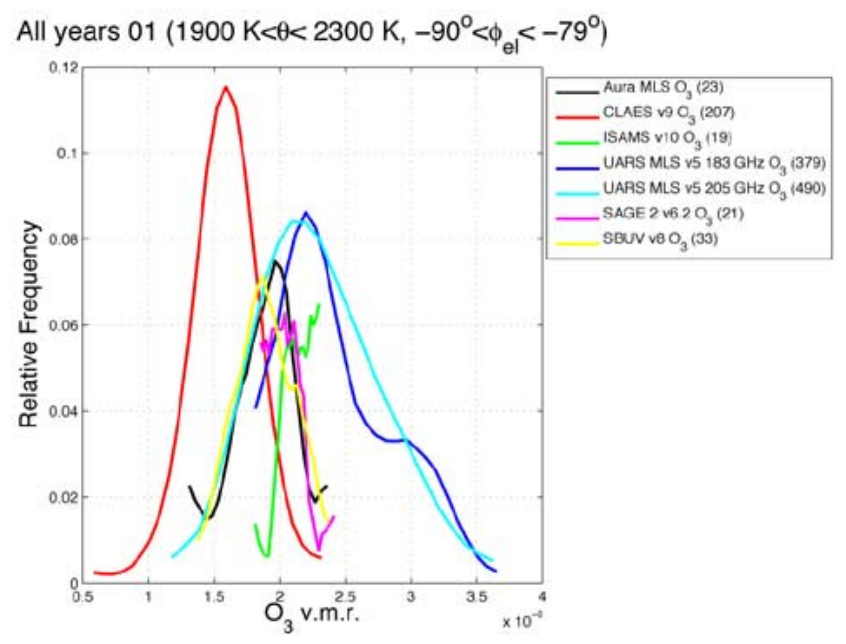

Fig. 2. Example of histograms of ozone observations using data during the January of all years from the launch of UARS in September 1991 until the present in the Lagrangian region $1900 K<\theta<2300 K,-90^{\circ}<\phi_{\mathrm{el}}<$ $-79^{\circ}$. For this Lagrangian region observations from seven different platforms were available including EOS Aura MLS in black.

lines) of around $0.75 \mathrm{ppmv}$. This is not restricted to this case but is a general feature of comparisons between CLAES and other instruments in the upper stratosphere. It is interesting that this is not true of CLAES observations in the lower stratosphere so the PDFs can be useful in examining spatially and temporally changing biases. In their overview of UARS ozone validation based primarily on intercomparisons among UARS and stratospheric aerosol and gas experiment II measurements Cunnold et al. [103] noted the relatively systematic, vertical structure differences between CLAES and other ozone observations.

The same approach has been used for many other instrument combinations and constituents. For example, Fig. 3 shows a comparison of $\mathrm{HNO}_{3}$ observations over the northern hemisphere from MLS and CLAES on the $500 \mathrm{~K}$ isentropic surface and demonstrates the use of PDFs in bias detection. When the MLS PDF (green line) is compared to CLAES (blue line), a clear bias of approximately $3.5 \mathrm{ppbv}$ can be seen for the primary (midlatitude) peak. However, the two PDFs cannot be brought into coincidence by an overall shift of the CLAES curve by this amount. Indicating that the differences between the measurements cannot be described as a simple bias. These types of discrepancies become clear from an analysis of the shape of the PDF. This type of analysis will be very useful for the validation of Aura datasets using coincident ensembles [29].

Other studies have also found issues with the CLAES $\mathrm{HNO}_{3}$ data. Kumer et al. [104] compared CLAES version 7 data to two ATMOS missions and found that the CLAES $\mathrm{HNO}_{3}$ maximum VMR values were of the order of 6\%-15\% less than correlative for CLAES values less than or equal to 8 parts per billion by volume (ppbv). In a data modeling comparison Chipperfield et al. [105] found that during the model initialization chemical inconsistencies in the UARS data became evident.

It is noteworthy that in the case of both $\mathrm{O}_{3}$ and $\mathrm{HNO}_{3}$ the interannual variability between the datasets (not all shown here) is less than the bias often found between the instruments. The obvious example of this is CLAES in Fig. 2.

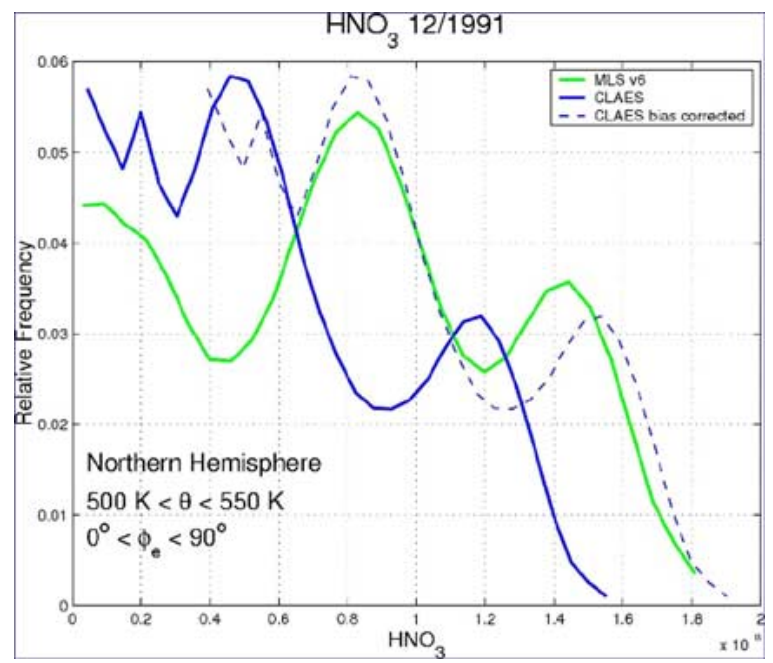

Fig. 3. $\mathrm{HNO}_{3}$ PDFs for UARS MLS (green line) and CLAES (blue line) on the $500 \mathrm{~K}$ isentropic surface for December 1991. There is an obvious bias of approximately $3.5 \mathrm{ppbv}$ for the primary (mid-latitude) peak at this altitude. Notice that a 3.5 ppbv shift of the CLAES curve (dashed blue line) does not bring the secondary peaks into complete coincidence, indicating that the biases are mixing ratio dependent.

\section{CONCLUSION}

A preliminary examination of EOS Aura MLS data indicates a good agreement with the historical ozone data record since the launch of UARS in 1991. The analysis used probability distribution functions to put the Aura data in a historical context. ${ }^{2}$ In this study we have restricted ourselves to considering PDFs in interinstrument bias detection. However, they could be used in many other ways, for example, using the shapes of the PDFs to examine mixing processes.

\section{ACKNOWLEDGMENT}

The authors would like to thank the following instrument teams for use of their data: The Atmospheric Chemistry Experiment (ACE); All NASA aircraft campaigns from the launch of UARS up-to the present, the Atmospheric Trace Molecule Experiment (ATMOS); the Microwave Limb Sounder (MLS) on NASA Earth Observing System (EOS) Aura and on UARS; the Cryogenic Limb Array Etalon Spectrometer (CLAES) on the Upper Atmosphere Research Satellite (UARS); the CRyogenic Infrared Spectrometers and Telescopes for the Atmosphere (CRISTA); the Halogen Occultation Experiment (HALOE) on UARS; the Improved Limb Atmospheric Spectrometer (ILAS); the Improved Stratospheric and Mesospheric Sounder (ISAMS) on UARS; the Measurement of Ozone and Water vapor by Airbus In-service Aircraft (MOZAIC) project; lidar and microwave observations from the Network for the Detection for Stratospheric Change (NDSC); the Polar Ozone and Aerosol Measurement Experiment (POAM) II and POAM III.; the Stratospheric Aerosol and Gas Experiment II (SAGE II); the NOAA Solar Backscatter UltraViolet Instrument (SBUV/2); ozone sondes from the World Ozone and Ultraviolet Radiation Data Centre (WOUDC).

\footnotetext{
${ }^{2}$ The analysis is presented online at http://www.PDFCentral.info.
} 


\section{REFERENCES}

[1] K. R. Mylne and P. J. Mason, "Concentration fluctuation measurements in a dispersing plume at a range of up to 1000-m," Q. J. R. Meteorol. Soc., vol. 117, no. 497, pp. 177-206, 1991.

[2] M. W. Rotach, S. E. Gryning, and C. Tassone, "A two-dimensional Lagrangian stochastic dispersion model for daytime conditions," $Q$. J. R. Meteorol. Soc., vol. 122, no. 530, pp. 367-389, 1996.

[3] T. Georgiadis, F. Fortezza, L. Alberti, V. Strocchi, A. Marani, and G. Dal Bo, "Probability density functions of photochemicals over a coastal area of northern Italy," Nuovo Cimento Della Soc. Ital. Fisica C-Geophys. Space Phys., vol. 21, no. 1, pp. 75-84, 1998.

[4] P. Franzese, A. K. Luhar, and M. S. Borgas, "An efficient Lagrangian stochastic model of vertical dispersion in the convective boundary layer," Atmos. Environ., vol. 33, no. 15, pp. 2337-2345, 1999.

[5] E. Ferrero, D. Anfossi, and G. Tinarelli, "Simulations of atmospheric dispersion in an urban stable boundary layer," Int. J. Chem. Environ. Pollution, vol. 16, no. 1-6, pp. 1-8, 2001.

[6] E. Yee and C. A. Biltoft, "Concentration fluctuation measurements in a plume dispersing through a regular array of obstacles," Bound. Layer Meteorol., vol. 111, no. 3, pp. 363-415, 2004.

[7] B. M. Bara, D. J. Wilson, and B. W. Zelt, "Concentration fluctuation profiles from a water channel simulation of a ground-level release," Atmos. Environ. A, vol. 26, no. 6, pp. 1053-1062, 1992.

[8] E. Yee, R. Chan, P. R. Kosteniuk, G. M. Chandler, C. A. Biltoft, and J. F. Bowers, "Concentration fluctuation measurements in clouds released from a quasi-instantaneous point-source in the atmospheric surface-layer," Bound. Layer Meteorol., vol. 71, no. 4, pp. 341-373, 1994.

[9] L. Ridolfi, P. D’Odorico, A. Porporato, and I. Rodriguez-Iturbe, "The influence of stochastic soil moisture dynamics on gaseous emissions of NO, $\mathrm{N}_{2} \mathrm{O}$, and $\mathrm{N}_{2}$," Hydrol. Sci. J., vol. 48, no. 5, pp. 781-798, 2003.

[10] R. T. Pierrehumbert, "Tracer microstructure in the large-eddy dominated regime," Chaos Solitons Fractals, vol. 4, no. 6, pp. 1091-1110, 1994.

[11] H. J. Yang, "3-dimensional transport of the Ertel potential vorticity and $\mathrm{N}_{2} \mathrm{O}$ in the GFDL skyhi model," J. Atmos. Sci., vol. 52, no. 9, pp. 1513-1528, 1995.

[12] L. C. Sparling and M. R. Schoeberl, "Mixing entropy analysis of dispersal of aircraft emissions in the lower stratosphere," J. Geophys. Res.-Atmos., vol. 100, no. D8, pp. 16805-16812, 1995.

[13] L. C. Sparling, J. A. Kettleborough, P. H. Haynes, M. E. McIntyre, J. E. Rosenfield, M. R. Schoeberl, and P. A. Newman, "Diabatic cross-isentropic dispersion in the lower stratosphere," J. Geophys. Res.-Atmos., vol. 102, no. D22, pp. 25 817-25 829, 1997.

[14] R. B. Rood, A. R. Douglass, M. C. Cerniglia, L. C. Sparling, and J. E. Nielsen, "Seasonal variability of middle-latitude ozone in the lowermost stratosphere derived from probability distribution functions," $J$. Geophys. Res.-Atmos., vol. 105, no. D14, pp. 17 793-17 805, 2000.

[15] L. C. Sparling, "Statistical perspectives on stratospheric transport," Rev. Geophys., vol. 38, no. 3, pp. 417-436, 2000.

[16] R. T. Pierrehumbert, "Lattice models of advection-diffusion," Chaos, vol. 10 , no. 1 , pp. 61-74, 2000.

[17] A. E. Andrews, K. A. Boering, S. C. Wofsy, B. C. Daube, D. B. Jones, S. Alex, M. Loewenstein, J. R. Podolske, and S. E. Strahan, "Empirical age spectra for the midlatitude lower stratosphere from in situ observations of CO2: Quantitative evidence for a subtropical "barrier' to horizontal transport," J. Geophys. Res.-Atmos., vol. 106, no. D10, pp. $10257-10274,2001$.

[18] L. C. Sparling and J. T. Bacmeister, "Scale dependence of tracer microstructure: PDFS, intermittency and the dissipation scale," Geophys. Res. Lett., vol. 28, no. 14, pp. 2823-2826, 2001.

[19] Y. Hu and R. T. Pierrehumbert, "The advection-diffusion problem for stratospheric flow. Part I: Concentration probability distribution function,” J. Atmos. Sci., vol. 58, no. 12, pp. 1493-1510, 2001.

[20] Y. Y. Hu and R. T. Pierrehumbert, "The advection-diffusion problem for stratospheric flow. Part II: Probability distribution function of tracer gradients," J. Atmos. Sci., vol. 59, no. 19, pp. 2830-2845, 2002.

[21] R. S. Gao, P. J. Popp, E. A. Ray, K. H. Rosenlof, M. J. Northway, D. W. Fahey, A. F. Tuck, C. R. Webster, D. F. Hurst, S. M. Schauffler, H. Jost, and T. P. Bui, "Role of $\mathrm{NO}_{\mathrm{y}}$ as a diagnostic of small-scale mixing in a denitrified polar vortex," J. Geophys. Res.-Atmos., vol. 107, no. D24, 2002.

[22] D. R. Johnson, A. J. Lenzen, T. H. Zapotocny, and T. K. Schaack, "Numerical uncertainties in simulation of reversible isentropic processes and entropy conservation: Part II," J. Climate, vol. 15, no. 14, pp. 1777-1804, 2002.

[23] S. Strahan, "Influence of planetary wave transport on arctic ozone as observed by polar ozone and aerosol measurement (POAM) III," J. Geophys. Res.-Atmos., vol. 107, no. D20, 2002.
[24] J. L. Neu, L. C. Sparling, and R. A. Plumb, "Variability of the subtropical "edges" in the stratosphere," J. Geophys. Res.-Atmos., vol. 108, no. D15, 4482, 2003.

[25] J. Hsu, M. J. Prather, O. Wild, J. K. Sundet, I. S. A. Isaksen, E. V. Browell, M. A. Avery, and G. W. Sachse, "Are the trace-p measurements representative of the western pacific during march 2001?," J. Geophys. Res.-Atmos., vol. 109, no. D2, D02314, 2004.

[26] M. Holzer and T. M. Hall, "Transit-time and tracer-age distributions in geophysical flows," J. Atmos. Sci., vol. 57, no. 21, pp. 3539-3558, 2000.

[27] M. Holzer, I. G. McKendry, and D. A. Jaffe, "Springtime trans-Pacific atmospheric transport from east asia: A transit-time probability density function approach," J. Geophys. Res.-Atmos., vol. 108, no. D22, 4708, 2003.

[28] D. Lary, "Representativeness uncertainty in chemical data assimilation highlight mixing barriers," Atmos. Sci. Lett., vol. 5, no. 1-4, pp. 35-41, 2003.

[29] L. Froidevaux et al., "Early validation analyses of atmospheric profiles from EOS MLS on the Aura satellite," IEEE Trans. Geosci. Remote Sens., vol. 44, no. 5, pp. 1106-1121, May 2006.

[30] A. Marenco, V. Thouret, P. Nedelec, H. Smit, M. Helten, D. Kley, F. Karcher, P. Simon, K. Law, J. Pyle, G. Poschmann, R. Von Wrede, C. Hume, and T. Cook, "Measurement of ozone and water vapor by airbus in-service aircraft: The MOZAIC airborne program, an overview," $J$. Geophys. Res.-Atmos., vol. 103, no. D19, pp. 25 631-25 642, 1998.

[31] P. Bernath, "Atmospheric chemistry experiment (ACE): An overview," in Spectroscopy from Space, ser. , 2001, vol. 20, pp. 147-160.

[32] C. Boone and P. Bernath, "The Atmospheric Chemistry Experiment (ACE)," Tech. Dig. Fourier Transform Spectrosc., vol. 51, pp. 27-28, 2001.

[33] K. A. Walker and P. F. Bernath, "Validation measurement program for the Atmospheric Chemistry Experiment (ACE)," Earth Observ. Systems VII, vol. 4814, pp. 91-101, 2002.

[34] P. F. Bernath, "Atmospheric Chemistry Experiment (ACE): Mission overview," Earth Observ. Systems IX, vol. 5542, pp. 146-156, 2004.

[35] C. D. Boone, K. A. Walker, S. D. McLeod, R. Nassar, and P. F. Bernath, "Atmospheric Chemistry Experiment (ACE): Mission overview and early results," Chem. Biol. Standoff Detection II, vol. 5584, pp. 230-240, 2004.

[36] P. Bernath et al., "Atmospheric Chemistry Experiment (ACE): Mission overview," Geophys. Res. Lett., to be published.

[37] M. Gunson, M. Abbas, M. Abrams, M. Allen, L. Brown, T. Brown, A. Chang, A. Goldman, F. Irion, L. Lowes, E. Mahieu, G. Manney, H. Michelsen, M. Newchurch, C. Rinsland, R. Salawitch, G. Stiller, G. Toon, Y. Yung, and R. Zander, "The Atmospheric Trace Molecule Spectroscopy (ATMOS) experiment: Deployment on the Atlas Space Shuttle missions," Geophys. Res. Lett., vol. 23, no. 17, pp. 2333-2336, 1996.

[38] W. A. Lahoz, "The $183 \mathrm{GHz}$ water and ozone channels on the Upper-Atmosphere Research Satellite Microwave Limb Sounder,' Int. J. Remote Sens., vol. 12, no. 1, pp. 33-53, 1991.

[39] F. T. Barath, M. C. Chavez, R. E. Cofield, D. A. Flower, M. A. Frerking, M. B. Gram, W. M. Harris, J. R. Holden, R. F. Jarnot, W. G. Kloezeman, G. J. Klose, G. K. Lau, M. S. Loo, B. J. Maddison, R. J. Mattauch, R. P. McKinney, G. E. Peckham, H. M. Pickett, G. Siebes, F. S. Soltis, R. A. Suttie, J. A. Tarsala, J. W. Waters, and W. J. Wilson, "The UpperAtmosphere Research Satellite Microwave Limb Sounder instrument," J. Geophys. Res.-Atmos., vol. 98, no. D6, pp. 10751-10 762, 1993.

[40] L. Froidevaux, W. G. Read, T. A. Lungu, R. E. Cofield, E. F. Fishbein, D. A. Flower, R. F. Jarnot, B. P. Ridenoure, Z. Shippony, J. W. Waters, J. J. Margitan, I. S. McDermid, R. A. Stachnik, G. E. Peckham, G. Braathen, T. Deshler, J. Fishman, D. J. Hofmann, and S. J. Oltmans, "Validation of UARS Microwave Limb Sounder ozone measurement," J. Geophys. Res.-Atmos., vol. 101, no. D6, pp. 10017-10060, 1996.

[41] R. F. Jarnot, R. E. Cofield, J. W. Waters, D. A. Flower, and G. E. Peckham, "Calibration of the Microwave Limb Sounder on the Upper Atmosphere Research Satellite," J. Geophys. Res.-Atmos., vol. 101, no. D6, pp. 9957-9982, 1996.

[42] J. W. Waters, W. G. Read, L. Froidevaux, R. F. Jarnot, R. E. Cofield, D. A. Flower, G. K. Lau, H. M. Pickett, M. L. Santee, D. L. Wu, M. A. Boyles, J. R. Burke, R. R. Lay, M. S. Loo, N. J. Livesey, T. A. Lungu, G. L. Manney, L. L. Nakamura, V. S. Perun, B. P. Ridenoure, Z. Shippony, P. H. Siegel, R. P. Thurstans, R. S. Harwood, H. C. Pumphrey, and M. J. Filipiak, "The UARS and EOS Microwave Limb Sounder (MLS) experiments," J. Atmos. Sci., vol. 56, no. 2, pp. 194-218, 1999.

[43] N. J. Livesey, W. G. Read, L. Froidevaux, J. W. Waters, M. L. Santee, H. C. Pumphrey, D. L. Wu, Z. Shippony, and R. F. Jarnot, "The UARS Microwave Limb Sounder version 5 data set: Theory, characterization, and validation,' J. Geophys. Res.-Atmos., vol. 108, no. D13, 4708, 2003. 
[44] M. R. Schoeberl, A. R. Douglass, E. Hilsenrath, M. Luce, J. Barnett, R. Beer, J. Waters, J. Gille, P. F. Levelt, and P. DeCola, "The EOS Aura mission," Proc. IGARSS, vol. 1-7, pp. 227-232, 2001.

[45] J. E. Johnson and S. P. Ahmad, "EOS Aura atmospheric chemistry data products," in Proc. IGARSS, 2004, pp. 4147-4149.

[46] P. M. Banks, W. T. Huntress, R. D. Hudson, C. A. Reber, C. A. Barth, C. B. Farmer, M. A. Geller, J. C. Gille, J. London, L. R. Megill, J. M. Russell III, R. G. Roble, R. S. Stolarski, and J. W. Waters, "Upper Atmosphere Research Satellite program," Jet Propulsion Lab., Pasadena, CA, 1978.

[47] C. A. Reber, C. E. Trevathan, R. J. Mcneal, and M. R. Luther, "The Upper-Atmosphere Research Satellite (UARS) mission," J. Geophys. Res.-Atmos., vol. 98, no. D6, pp. 10 643-10 647, 1993.

[48] C. Reber, C. Trevathan, R. Mcneal, and M. Luther, "TheUpper-Atmosphere Research Satellite (UARS) mission," J. Geophys. Res., vol. 98, no. D6, pp. 10 643-10 647, 1993.

[49] M. Riese, P. Preusse, R. Spang, M. Ern, M. Jarisch, K. U. Grossmann, and D. Offermann, "Measurements of trace gases by the Cryogenic Infrared Spectrometers and Telescopes for the Atmosphere (CRISTA) experiment," in Middle Upper Atmos.: Small Scale Struct. Remote Sens., 1997, vol. 19, pp. 563-566.

[50] D. Offermann, K. U. Grossmann, P. Barthol, P. Knieling, M. Riese, and R. Trant, "Cryogenic Infrared Spectrometers and Telescopes for the Atmosphere (CRISTA) experiment and middle atmosphere variability," J. Geophys. Res.-Atmos., vol. 104, no. D13, pp. $16311-16325,1999$.

[51] M. Riese, R. Spang, P. Preusse, M. Ern, M. Jarisch, D. Offermann, and K. U. Grossmann, "Cryogenic Infrared Spectrometers and Telescopes for the Atmosphere (CRISTA) data processing and atmospheric temperature and trace gas retrieval," J. Geophys. Res.-Atmos., vol. 104, no. D13, pp. 16349-16367, 1999.

[52] J. M. Russell, L. L. Gordley, J. H. Park, S. R. Drayson, W. D. Hesketh, R. J. Cicerone, A. F. Tuck, J. E. Frederick, J. E. Harries, and P. J. Crutzen, "The Halogen occultation experiment," J. Geophys. Res.-Atmos., vol. 98, no. D6, pp. 10777-10797, 1993.

[53] J. M. Russel, L. L. Gordley, L. E. Deaver, R. E. Thompson, and J. H. Park, "An overview of the Halogen OccultationEexperiment (HALOE) and preliminary Results," Earths Middle Atmos., vol. 14, no. 9, pp. 13-20, 1994.

[54] J. E. Harries, J. M. Russell, A. F. Tuck, L. L. Gordley, P. Purcell, K. Stone, R. M. Bevilacqua, M. Gunson, G. Nedoluha, and W. A. Traub, "Validation of measurements of water vapor from the Halogen Occultation Experiment (HALOE)," J. Geophys. Res.-Atmos., vol. 101, no. D6, pp. 10205-10216, 1996

[55] M. Suzuki, A. Matsuzaki, T. Ishigaki, N. Kimura, N. Araki, T. Yokota, and Y. Sasano, "ILAS, the Improved Limb Atmospheric Spectrometer, on the Advanced Earth Observing Satellite," IEICE Trans. Commun., vol. E78B, no. 12, pp. 1560-1570, 1995.

[56] T. Yokota, M. Suzuki, O. V. Dubovik, and Y. Sasano, "ILAS (Improved Limb Atmospheric Spectrometer) ADEOA data retrieval algorithms," in Remote Sens.: Inversion Problems Natural Hazards, 1998, vol. 21, pp. 393-396.

[57] Y. Sasano, M. Suzuki, T. Yokota, and H. Kanzawa, "Improved Limb Atmospheric Spectrometer (ILAS) for stratospheric ozone layer measurements by solar occultation technique," Geophys. Res. Lett., vol. 26, no. 2, pp. 197-200, 1999.

[58] H. Irie, Y. Kondo, M. Koike, M. Y. Danilin, C. Camy-Peyret, S. Payan, J. P. Pommereau, F. Goutail, H. Oelhaf, G. Wetzel, G. C. Toon, B. Sen, R. M. Bevilacqua, J. M. Russell, J. B. Renard, H. Kanzawa, H. Nakajima, T. Yokota, T. Sugita, and Y. Sasano, "Validation of $\mathrm{NO}_{2}$ and $\mathrm{HNO}_{3}$ measurements from the Improved Limb Atmospheric Spectrometer (ILAS) with the version 5.20 retrieval algorithm," J. Geophys. Res.-Atmos., vol. 107, no. D24, 8206, 2002.

[59] H. Nakajima, M. Suzuki, A. Matsuzaki, T. Ishigaki, K. Waragai, Y. Mogi, N. Kimura, N. Araki, T. Yokota, H. Kanzawa, T. Sugita, and Y. Sasano, "Characteristics and performance of the Improved Limb Atmospheric Spectrometer (ILAS) in orbit," J. Geophys. Res.-Atmos., vol. 107, no. D24, 2002.

[60] T. Yokota, H. Nakajima, T. Sugita, H. Tsubaki, Y. Itou, M. Kaji, M. Suzuki, H. Kanzawa, J. H. Park, and Y. Sasano, "Improved Limb Atmospheric Spectrometer (ILAS) data retrieval algorithm for version 5.20 gas profile products," J. Geophys. Res.-Atmos., vol. 107, no. D24, 2002

[61] C. J. Marks and C. D. Rodgers, "A retrieval method for atmospheric composition from limb emission measurements," J. Geophys. Res._Atmos., vol. 98, no. D8, pp. 14 939-14 953, 1993.
[62] F. W. Taylor, C. D. Rodgers, J. G. Whitney, S. T. Werrett, J. J. Barnett, G. D. Peskett, P. Venters, J. Ballard, C. W. P. Palmer, R. J. Knight, P. Morris, T. Nightingale, and A. Dudhia, "Remote-sensing of atmospheric structure and composition by pressure modulator radiometry from space-The ISAMS experiment on UARS," J. Geophys. Res.-Atmos., vol. 98, no. D6, pp. 10799-10814, 1993.

[63] F. W. Taylor, J. Ballard, A. Dudhia, M. Gosscustard, B. J. Kerridge, A. Lambert, M. Lopezvalverde, C. D. Rodgers, and J. J. Remedios, "Stratospheric and mesospheric observations with ISAMS," Earths Middle Atmos., vol. 14, no. 9, pp. 41-52, 1994.

[64] J. Ballard, C. W. P. Palmer, P. E. Morris, T. J. Nightingale, J. Firth, R. J. Knight, P. Venters, R. J. Wells, and J. G. Whitney, "Calibration of the Improved Stratospheric and Mesospheric Sounder.1. Introduction, spectral, and radiometric calibration," J. Atmos. Oceanic Technol., vol. 13, no. 4, pp. 810-831, 1996.

[65] C. D. Rodgers, R. J. Wells, R. G. Grainger, and F. W. Taylor, "Improved Stratospheric and Mesospheric Sounder validation: General approach and in-flight radiometric calibration," J. Geophys. Res.-Atmos., vol. 101, no. D6, pp. 9775-9793, 1996.

[66] R. M. Bevilacqua, E. P. Shettle, J. S. Hornstein, P. R. Schwartz, D. T. Chen, M. Fromm, W. Glaccum, J. D. Lumpe, S. S. Krigman, D. Debrestian, D. W. Rusch, C. E. Randall, R. T. Clancy, and J. J. Olivero, "The Polar Ozone and Aerosol Measurement Experiment (Poam-II)," Opt. Spectrosc. Techn. Instrum. Atmos. Space Res., vol. 2266, pp. 374-382, 1994.

[67] E. P. Shettle, R. M. Bevilacqua, J. S. Hornstein, K. Hoppel, J. Lumpe, S. Krigman, D. Debrestian, M. Fromm, and W. J. Glaccum, "POAM II: Early results and comparisons with the COSPAR international reference atmosphere ozone models," Cospar Int. Ref. Atmos. (Cira), Pt. III, vol. 18 , no. $9 / 10$, pp. 311-314, 1996.

[68] J. D. Lumpe, R. M. Bevilacqua, K. W. Hoppel, S. S. Krigman, D. L. Kriebel, D. J. Debrestian, C. E. Randall, D. W. Rusch, C. Brogniez, R. Ramananaherisoa, E. P. Shettle, J. J. Olivero, J. Lenoble, and P. Pruvost, "POAM II retrieval algorithm and error analysis," J. Geophys. Res.-Atmos., vol. 102, no. D19, pp. 23 593-23 614, 1997.

[69] C. Brogniez, I. Jankowiak, P. Pruvost, J. Lenoble, J. D. Lumpe, and R. M. Bevilacqua, "POAM III instrument: Comparison of 2 algorithms for atmospheric species retrieval," IRS 2000: Current Problems Atmospheric Radiat., pp. 773-776, 2001.

[70] J. D. Lumpe, R. M. Bevilacqua, K. W. Hoppel, and C. E. Randall, "POAM III retrieval algorithm and error analysis," J. Geophys. Res.-Atmos., vol. 107, no. D21, 4575, 2002.

[71] N. H. Zaun, L. E. Mauldin, and M. P. McCormick, "Design and performance of the Stratospheric Aerosol and Gas Experiment-II (SAGE-II) instrument," Proc. SPIE, vol. 430, pp. 99-105, 1983.

[72] H. J. Wang, D. M. Cunnold, L. W. Thomason, J. M. Zawodny, and G E. Bodeker, "Assessment of SAGE version 6.1 ozone data quality," $J$. Geophys. Res.-Atmos., vol. 107, no. D23, 4691, 2002.

[73] D. F. Heath, A. J. Krueger, H. A. Roeder, and B. D. Henderson, "Solar Backscatter Ultraviolet and Total Ozone Mapping Spectrometer (SBUVTOMS) for Nimbus G," Opt. Eng., vol. 14, no. 4, pp. 323-331, 1975.

[74] E. Hilsenrath, R. P. Cebula, M. T. Deland, K. Laamann, S. Taylor, C. Wellemeyer, and P. K. Bhartia, "Calibration of the NOAA-11 Solar Backscatter Ultraviolet (SBUV/2) ozone data set from 1989 to 1993 using in-flight calibration data and SSBUV," J. Geophys. Res.-Atmos., vol. 100, no. D1, pp. 1351-1366, 1995.

[75] W. G. Planet, A. J. Miller, K. Horvath, R. Nagatani, L. E. Flynn, E. Hilsenrath, S. Kondragunta, R. P. Cebula, and M. T. DeLand, "Total ozone determinations from National Oceanic and Atmospheric Administration operational Solar Backscattered Ultraviolet 2 instrument observations: An update," J. Geophys. Res._Atmos., vol. 106, no. D15, pp. $17471-17478,2001$.

[76] A. J. Miller, R. M. Nagatani, L. E. Flynn, S. Kondragunta, E. Beach, R Stolarski, R. D. McPeters, P. K. Bhartia, M. T. DeLand, C. H. Jackman, D. J. Wuebbles, K. O. Patten, and R. P. Cebula, "A cohesive total ozone data set from the SBUV/2 satellite system," J. Geophys. Res.-Atmos., vol. 107 , no. D23, 4701, 2002.

[77] M. J. Kurylo, "Network for the detection of stratospheric change (NDSC)," Remote Sens. Atmos. Chem., vol. 1491, pp. 168-174, 1991.

[78] I. S. McDermid, J. B. Bergwerff, G. Bodeker, I. S. Boyd, E. J. Brinksma, B. J. Connor, R. Farmer, M. R. Gross, P. Kimvilakani, W. A. Matthews, T. J. McGee, F. T. Ormel, A. Parrish, U. Singh, D. P. J. Swart, J. J. Tsou, P. H. Wang, and J. Zawodny, "OPAL: Network for the detection of stratospheric change ozone profiler assessment at Lauder, New Zealand 1 Blind intercomparison," J. Geophys. Res.-Atmos., vol. 103, no. D22, pp. $28683-28692,1998$. 
[79] B. M. Sinnhuber, S. Langer, U. Klein, U. Raffalski, and K. Kunzi, "Ground based millimeter-wave observations of Arctic ozone depletion during winter and spring of 1996/97," Geophys. Res. Lett., vol. 25, no. 17 , pp. 3327-3330, 1998.

[80] M. R. Schoeberl, L. C. Sparling, C. H. Jackman, and E. L. Fleming, "A Lagrangian view of stratospheric trace gas distributions," J. Geophys. Res.-Atmos., vol. 105, no. D1, pp. 1537-1552, 2000.

[81] R. Taylor, "The topography of the $400 \mathrm{k}$ isentropic surface over Antarctica: Spring 1957," Nat. Acad. Sci., IGY Rep. No. 11, 1960.

[82] E. Danielsen, "Trajectories-Isobaric, isentropic, and actual," J. Meteorol., vol. 18, no. 4, pp. 479-486, 1961.

[83] E. Danielsen, "Stratospheric-tropospheric exchange based on radioactivity ozone and potential vorticity," J. Atmos. Sci., vol. 25, no. 3, p. 502, 1968.

[84] E. Danielsen, R. Bleck, J. Shedlovs, A. Wartburg, P. Haagenso, and W. Pollock, "Observed distribution of radioactivity, ozone, and potential vorticity associated with tropopause folding," J. Geophys. Res., vol. 75, no. 12 , p. 2353, 1970.

[85] M. McIntyre and T. Palmer, "Breaking planetary-waves in the stratosphere," Nature, vol. 305, no. 5935, pp. 593-600, 1983.

[86] _ "The surf zone in the stratosphere," J. Atmos. Terr. Phys., vol. 46, no. 9, pp. 825-849, 1984.

[87] B. Hoskins, M. McIntyre, and A. Robertson, "On the use and significance of isentropic potential vorticity maps," $Q . J$. R. Meteorol. Soc., vol. 111, no. 470, pp. 877-946, 1985.

[88] B. Hoskins, "Toward a PV-theta view of the general-circulation," Tellus, Ser. A., vol. 43, no. 4, pp. 27-35, 1991.

[89] M. E. McIntyre, "Toward a Lagrangian-mean description of stratospheric circulations and chemical transports," Phil. Tran. R. Soc. London Series A-Math. Phys. Eng. Sci., vol. 296, no. 1418, pp. 129-148, 1980.

[90] _ - "An introduction to the generalized Lagrangian-mean description of wave, mean-flow interaction," Pure Appl. Geophys., vol. 118, no. 1-2, pp. $152-176,1980$

[91] C. B. Leovy, C. R. Sun, M. H. Hitchman, E. E. Remsberg, J. M. Russell, L. L. Gordley, J. C. Gille, and L. V. Lyjak, "Transport of ozone in the middle stratosphere-Evidence for planetary wave breaking," J. Atmos. Sci., vol. 42, no. 3, pp. 230-244, 1985.

[92] N. Butchart and E. E. Remsberg, "The area of the stratospheric polar vortex as a diagnostic for tracer transport on an isentropic surface," $J$. Atmos. Sci., vol. 43, no. 13, pp. 1319-1339, 1986.

[93] M. R. Schoeberl, L. R. Lait, P. A. Newman, R. L. Martin, M. H. Proffitt, D. L. Hartmann, M. Loewenstein, J. Podolske, S. E. Strahan, J. Anderson, K. R. Chan, and B. Gary, "Reconstruction of the constituent distribution and trends in the Antarctic polar vortex from ER-2 flight observations," J. Geophys. Res.-Atmos., vol. 94, no. D14, pp. 16815-16845, 1989.

[94] M. Schoeberl and L. Lait, "Conservative-coordinate transformations for atmospheric measurements," EOS Stud. Atmos. Phys., pp. 419-431, 1992.

[95] W. Norton, "Breaking Rossby waves in a model stratosphere diagnosed by a vortex-following technique for advecting material contours," $J$. Atmos. Sci., vol. 51, no. 4, pp. 654-673, 1994.

[96] D. Lary, M. Chipperfield, J. Pyle, W. Norton, and L. Riishojgaard, "3-dimensional tracer initialization and general diagnostics using equivalent PV latitude-potential-temperature coordinates," Q. J. R. Meteorol. Soc., vol. 121 , no. 521, pp. 187-210, 1995.

[97] M. Proffitt, M. Steinkamp, J. Powell, R. Mclaughlin, O. Mills, A. Schmeltekopf, T. Thompson, A. Tuck, T. Tyler, R. Winkler, and K. Chan, "Insitu ozone measurements within the 1987 Antarctic ozone hole from a high-altitude ER-2 aircraft," J. Geophys. Res.-Atmos., vol. 94, no. D14, pp. 16547-16555, 1989.

[98] L. Lait, M. Schoeberl, P. Newman, M. Proffitt, M. Loewenstein, J. Podolske, S. Strahan, K. Chan, B. Gary, J. Margitan, E. Browell, M. Mccormick, and A. Torres, "Reconstruction of $\mathrm{O}_{3}$ and $\mathrm{N}_{2} \mathrm{O}$ fields from ER-2, DC-8, and balloon observations," Geophys. Res. Lett., vol. 17, no. 4, pp. 521-524, 1990.

[99] A. Douglass, R. Rood, R. Stolarski, M. Schoeberl, M. Proffitt, J. Margitan, M. Loewenstein, J. Podolske, and S. Strahan, "Global three-dimensional constituent fields derived from profile data," Geophys. Res. Lett., vol. 17, no. 4, pp. 525-528, 1990.

[100] M. Proffitt, K. Aikin, J. Margitan, M. Loewenstein, J. Podolske, A Weaver, K. Chan, H. Fast, and J. Elkins, "Ozone loss inside the northern polar vortex during the 1991-1992 winter," Science, vol. 261, no. 5125, pp. 1150-1154, 1993.
[101] "An observational study of the austral spring stratosphere: Dynamics, ozone transport and the ozone dilution effect," Ph.D. dissertation, Mass. Inst. Technol., Cambridge, 1993.

[102] J. Remedios, "UARS Reference Atmosphere,", http://code916.gsfc. nasa.gov/Public/Analysis/UARS/urap/home.html, 2001.

[103] D. M. Cunnold, L. Froidevaux, J. M. Russell, B. Connor, and A. Roche, "Overview of UARS ozone validation based primarily on intercomparisons among UARS and Stratospheric Aerosol and Gas Experiment II measurements," J. Geophys. Res.-Atmos., vol. 101, no. D6, pp. 10335-10350, 1996.

[104] J. B. Kumer, J. L. Mergenthaler, A. E. Roche, R. W. Nightingale, G. A. Ely, W. G. Uplinger, J. C. Gille, S. T. Massie, P. L. Bailey, M. R. Gunson, M. C. Abrams, G. C. Toon, B. Sen, J. F. Blavier, R. A. Stachnik, C. R. Webster, R. D. May, D. G. Murcray, F. J. Murcray, A. Goldman, W. A. Traub, K. W. Jucks, and D. G. Johnson, "Comparison of correlative data with $\mathrm{HNO}_{3}$ version 7 from the CLAES instrument deployed on the NASA Upper Atmosphere Research Satellite," J. Geophys. Res._Atmos., vol. 101, no. D6, pp. 9621-9656, 1996.

[105] M. Chipperfield, M. Santee, L. Froidevaux, G. Manney, W. Read, J. Waters, A. Roche, and J. Russell, "Analysis of UARS data in the southern polar vortex in September 1992 using a chemical transport model," $J$. Geophys. Res., vol. 101, no. D13, pp. 18 861-18 881, 1996.

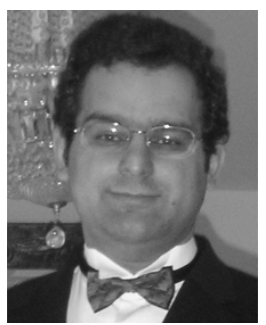

David J. Lary received the B.Sc. degree in physics and chemistry (first class double honors) from King's College London, London, U.K., in 1987 with the Sambrooke Exhibition Prize in Natural Science, and the Ph.D. degree in atmospheric chemistry from the Churchill College, University of Cambridge, Cambridge, U.K., in 1991. His thesis described the first chemical scheme for the ECMWF numerical weather prediction model.

He then held postdoctoral Research Assistant and Associate positions at Cambridge University until receiving a Royal Society University Research Fellowship in 1996 (also at Cambridge). From 1998 to 2000, he held a joint position at Cambridge and the University of Tel-Aviv, Tel-Aviv, Israel, as a Senior Lecturer and Alon Fellow. In 2000, the Chief Scientific Adviser to the British Prime Minister and Head of the British Office of Science and Technology, Professor Sir D. King, recommended him to be appointed as a Cambridge University Lecturer in chemical informatics. In 2001, he joined the University of Maryland Baltimore County (UMBC/GEST), Baltimore, as the first distinguished Goddard Fellow in earth science. He is currently involved with NASA Aura validation using probability distribution functions and chemical data assimilation, neural networks for accelerating atmospheric models, the use of Earth Observing data for health and policy applications, and the optimal design of Earth Observing Systems. The thread running through all the research is atmospheric chemistry and the use of observation and automation to facilitate scientific discovery.

Dr. Lary's automatic code generation software, AutoChem, has received three NASA awards and has been recommended for the NASA Software of the Year Award.

Leslie Lait received the B.A. degree in physics and mathematics from Union College, Lincoln, NE, in 1981 and the Ph.D. degree in physics from Iowa State University, Ames, in 1987. His doctoral thesis described the first applications of M. Salby's asynoptic space-time Fourier transform analysis to real satellite measurements.

After graduating from Iowa State, he spent two years as a National Research Council Fellow at NASA's Goddard Space Flight Center, Greenbelt, MD. Subsequently, he remained at Goddard, where his research has centered on applications of quasi-conservative coordinate analysis of noncoincident measurements of trace gases from satellite remote-sensing instruments and airborne in situ instruments. He currently provides support for field experiments for validating the EOS Aura instruments. 